\title{
DOI https://doi.org/10.30525/978-9934-26-041-4-38
}

\section{ДІАЛОГ У КОНТЕКСТІ ПЕДАГОГІЧНОЇ ВЗАЕМОДІЇ: ГУМАНІСТИЧНИЙ АСПЕКТ}

\author{
Божко Н. М. \\ кандидат філологічних наук, \\ дочент кафедри мовної підготовки \\ Харківський національний автомобільно-дорожній університет \\ Кудрявцев В. М. \\ кандидат економічних наук, \\ доиент кафедри економіки і підприємства \\ Харківський національний автомобільно-дорожній університет \\ Кісіль Л. М. \\ стариий викладач кафедри мовної підготовки \\ Харківський національний автомобільно-дорожній університет \\ м. Харків, Україна
}

Система вищої освіти в Україні формується як один із пріоритетних напрямів і ціннісних орієнтацій державності та суспільної свідомості. Провідним принципом освіти $є$ гуманістична спрямованість навчальновиховного процесу, що передбачає створення умов для розкриття та розвитку здібностей студента, його позитивної самореалізації. Формування гуманістичної свідомості, моральних та культурних норм і цінностей на засадах діалогової взаємодії - довготривалий процес, тому саме освіта покликана бути інститутом гуманізації суспільства й кожної особистості. Професійна педагогічна діяльність викладача як носія духовних цінностей покликана сприяти формуванню гуманної, демократичної особистості, що передбачає насамперед розвиток відповідного світобачення, діалогічного буття. Крім того, глобальні тенденції розвитку сучасного суспільства, збільшення міжнародних, культурних та економічних зв'язків України 3 іншими країнами, динамічність і мобільність викликають необхідність щодо діалогізації будь-якої професійної діяльності, що визначає актуальність дослідження діалогічної проблематики.

Проблеми діалогу та діалогічності, що $є$ надзвичайно різноаспектними, неодноразово ставали центром уваги багатьох учених у різних галузях. Зауважимо, що діалог завжди був об'єктом вивчення у педагогів, філософів, психологів, лінгвістів та ін. Перші спроби 
осмислення діалогу було зроблено у стародавні часи. Так, у працях філософів та педагогів Конфуція, М. Квінтиліана, Дж. Локка, Я. Коменського, Сократа, Платона, Ф. Шлейсрмахера та інших можемо побачити витоки теорії навчального діалогу, хоча передусім мислителі розглядали діалог як засіб пізнання, самосвідомості, самопізнання особистості, знаходження істини. Пізніше вчені М. Бахтін, М. Бубер, К. Ясперс презентували діалог як основу людського співбуття й самобуття, специфічного способу реалізації сутності людини як засобу духовного єднання людей та їхнього духовного просвітлення [3, с. 2]. Діалог як підгрунтя педагогічного спілкування, взаємодію різних смислових позицій у контексті філософського та культурологічного підходів висвітлено у працях В. Біблера, Е. Ільєнкова, М. Кагана, Л. Когана та ін. Педагогічну майстерність організації діалогу в навчальному процесі досліджують А. Алексюк, О. Березюк, І. Зязюн, М. Свтух, Л. Крамущенко, О. Киричук та ін. Дидактичні аспекти організації діалогу в навчальному процесі відображено у наукових розвідках Л. Балакіної, В. Андрієвської, Л. Даниленко, В. Дьяченка, М. Лазарєва, В. Морозова, І. Риданової, В. Сєрікова, С Курганова та ін. Важливе місце у педагогічних та психологічних дослідженнях посідає питання діалогічної стратегії взаємодії, яке розглянуто у працях Г. Балла, I. Беха, І. Гапійчук, І. Зимньої, М. Кагана, Г. Ковальова та ін. Учені Ш. Амонашвілі, О.Бодальов, Н.Волкова, Ю.Гільбух, Т.Іванова, О. Матюшкін, С. Мусатов, В. Панюшкін акцентували увагу на діалозі як провідному принципі професійного спілкування.

Однак, попри численні наукові розвідки, що демонструють різні підходи до визначення змісту поняття «діалог» та різноманітність його тлумачення у мовленнєвій практиці, виникає суперечливе розуміння діалогічної ситуації, іiі природи, закономірностей розвитку i функціонування. У зв'язку з цим $є$ потреба чітко розмежовувати діалог як форму спілкування, форму і засіб проблемного навчання та діалогічну взаємодію як психолого-педагогічну умову гуманізації сучасного освітнього процесу [4, с. 18]. Крім того, характер педагогічної взаємодії викладача і студентів впливає на вибір форм організації і методів навчання, які дозволяють викладачу допомагати особистіснопрофесійному зростанню майбутнього фахівця, ефективніше здійснювати контроль за ходом пізнавальної діяльності студентів, а також сприяти розвиткові творчої особистості і формуванню гуманного ставлення до оточуючих. Як бачимо, проблема побудови навчального процесу на принципах діалогічного спілкування, співпраці й співтворчості є особливо актуальною. 
3 огляду на вищевикладене сформульовано мету дослідження, що полягає у розгляді наукових засад процесу організації навчального діалогу як чинника успішної зорієнтованої педагогічної взаємодії викладача і студента на засадах гуманізму.

Оскільки діалог (грец. dialogos - розмова, бесіда) - форма соціально-мовного спілкування, основа співробітництва й взаєморозуміння між людьми у процесі спільної діяльності, що передбачає рівність учасників спілкування, то в науковій літературі дослідники розглядають діалог через призму «комунікативних прав»: право на власну систему цінностей, гідність i повагу, індивідуальність i своєрідність, незалежність і суверенітет, відстоювання власних прав, право на самовизначення [2, с. 211]. У процесі педагогічної взаємодії викладач не завжди готовий будувати стосунки зі студентами на діалогічній основі, використовуючи навчальний діалог як форму спілкування, навчання і засіб творчого розвитку особистості студента. Якщо на заняттях і наявний діалог, то він найчастіше виступає лише організаційною формою, а не педагогічною цінністю, принципом, умовою творчої співпраці викладача й студента, яка має бути направлена на самовдосконалення особистості майбутнього спеціаліста [3, с. 1]. У зв'язку з тим, що в навчальному процесі недостатньо використовується діалогічна взаємодія, викладачі здебільшого розглядають професійну підготовку студентів у відриві від гуманістичної парадигми розвитку системи освіти або приділяють увагу лише формуванню знань гуманістичного характеру. Зазначимо, що діалогічність в освіті - особлива форма відносин між рівноправними суб'єктами гуманістичної форми взаємодії, що не допускає будь-якого домінування в комунікативній взаємодії i передбачає свободу думок та відповідальність за дії і рішення [1, с. 8]. Крім того, професійна діяльність викладача за своєю природою i результатами має бути гуманістичною, а тому вимагає гуманістичних відносин між суб'єктами педагогічної взаємодії.

Навчальний діалог є цілеспрямованою, організованою взаємодією суб'єктів педагогічного процесу, будується на принципах співпраці, співтворчості, передбачає наявність проблеми, що має різні варіанти вирішення, бажання студентів у процесі взаємного обміну думками знайти в різних відповідях найбільш оптимальну. Навчальний діалог виконує інформативну, регулювальну функції та забезпечує розвивальний характер навчання [5, с. 161]. Він має бути гуманістично зорієнтованим, коли викладач, спілкуючись зі студентом, намагається зрозуміти та прийняти його позицію або ж об'єктивно 3'ясувати причини її неприйняття. 
Слід зазначити, що підготовку майбутнього спеціаліста не можна вважати успішною, якщо за наявності високого рівня професійних знань та вмінь у нього не сформовано гуманність як найвищу особистісну рису людини. Звідси логічно випливає єдність професійної підготовки та ії гуманістичного аспекту.

Таким чином, за умов гуманістичної спрямованості освіти діалогічність у процесі педагогічної взаємодії $є$ одним із провідних методологічних підходів, тому діалогізацію дидактичного процесу вважаємо визначальною умовою підготовки майбутніх фахівців у закладах вищої освіти. Діалог у контексті педагогічної взаємодії викладача і студентів сприяє активізації пізнавальної і мовленнєвої діяльності майбутніх спеціалістів, підвищує рівень їхньої мотивації до навчання, розвиває вміння самостійно $\mathrm{i}$ творчо мислити та застосовувати здобуті знання у практичній діяльності, створює позитивну атмосферу для формування самодостатньої, незалежної i свідомої особистості. Крім того, запровадження діалогічності в освітньому процесі дає змогу сформувати комунікативні вміння в різних видах мовленнєвої діяльності, а також сприяти побудові діалогічних відносин на основі гуманності, рівності й толерантності.

Репрезентоване дослідження не вичерпує всього кола питань, пов'язаних зі специфікою діалогічної взаємодії у навчально-виховному процесі. Перспективи подальших розвідок у цьому напрямі вбачаємо у подальшому розкритті змісту освітнього потенціалу діалогічного підходу до процесу професійної підготовки фахівців у закладах вищої освіти України.

\section{Література:}

1. Борисенко В.В. Діалог у контексті сучасної освітньої парадигми. Вісник Чернігівського начіонального педагогічного університету. Серія «Педагогічні науки». 2015. Вип. 124. С. 8-10.

2. Братченко С. Л. Межличностный диалог и его основные атрибуты. Психология с человеческим лицом: гуманистическая перспектива в постсоветской психологии. Москва: Смысл, 1997. C. 201-222.

3. Глазкова І.Я. Підготовка майбутнього вчителя до організації навчального діалогу в професійній діяльності: автореф. дис. ... канд. пед. наук: 13.00.04. Харків. 2004. 25 с.

4. Зазуліна Л.В. Діалогізація дидактичного процесу: гуманістична перспектива / за ред. А.В. Фурмана. Київ: Правда Ярославовичів, 1998. $64 \mathrm{c}$. 
5. Шепеленко Т.Л. Діалогове навчання як умова формування комунікативної компетентності студентів економічного університету. Педагогіка і психологія формування творчої особистості: проблеми $i$ пошуки : збірник наукових праць / за ред. T.I. Сущенко. КиївЗапоріжжя, 2002. Вип. 22. С. 158-163.

\title{
DOI https://doi.org/10.30525/978-9934-26-041-4-39
}

\section{ПРОБЛЕМА ФОРМУВАННЯ СТУДЕНТА-ГУМАНІСТА В УМОВАХ ДІДЖЕТАЛІЗАЦІЇ ОСВІТНЬОГО СЕРЕДОВИЩА}

\author{
Бойван О. С.
}

кандидат педагогічних наук, старший викладач кафедри теорії та практики перекладу Донеиький наиіональний університет імені Василя Стуса

Ковтун О. В.

кандидат філологічних наук, старший викладач кафедри теорії та практики перекладу Донеиький начіональний університет імені Василя Стуса м. Вінниця, Украӥна

Сучасний етап досліджень проблеми формування студентагуманіста має характеристики активного пошуку іiі еталонних зразків, що описуються за допомогою різноманітних термінів, понять, категорій i, зокрема, дефініції молодої людини, орієнтації якої спрямовані не тільки на результативність навчально-виховного процесу, а й на інтегральний, глибоко моральний феномен бачення свого єства, що базується на позитивній людській взаємодії. Проблема формування студента-гуманіста $\epsilon$ актуальною для навчально-виховного процесу, особливо студентської молоді, від якої залежить не тільки майбутнє країни, а й окремо взятої особистості, яка є невід'ємним і важливим компонентом морально здорової нації. Наголошуємо на тому факті, що технократизоване сьогодення може стати тригером негативізму у процесі зародження основ гуманності, яка $з$ трендів ніколи не вийде, оскільки $є$ однією 3 основоположних фундаментальних практик людських стосунків та особливостей нашого співжиття. У нашій науковій розвідці прагнемо підкреслити важливість урівноваження двох понять: студент-гуманіст та діджеталізація суспільства і показати 